¿Cómo aprendieron los futuros maestros de escuela primaria en Indonesia la educación para la ciudadanía durante la pandemia de Covid 19?

\title{
How Did Prospective Elementary School Teacher Learn Citizenship Education during the Pandemic Covid-19 in Indonesia?
}

Yayuk Hidayah. Ahmad Dahlan University, Yogyakarta.

Yayuk.hidayah@pgsd.uad.ac.id

\begin{abstract}
Lili Halimah. High School for Teacher Training and Education (STKIP) Pasundan Cimahi, Cimahi. lili.halimah@gmail.com

Meiwatizal Trihastuti.
\end{abstract} High School for Teacher Training and Education (STKIP) Pasundan Cimahi, Cimahi. meiwatizal@gmail.com

Dinie Anggraeni Dewie. Indonesia University of Education, Bandung. dinieanggraenidewidhinie@gmail.com

Yoga Ardian Feriandi. Universitas PGRI Madiun, Madiun, Indonesia. feriandi.ardhiyan28@gmail.com

Dianasari Dianasari. Muhammadiyah University of Cirebon, Cirebon. dianasari@umc.ac.id

\section{RESUMEN.}

Numerosos problemas como el resultado de la pandemia de Covid-19 han continuado apareciendo en varios sectores a medida que se propaga rápidamente. En el sector educativo, los estudiantes ya no pueden estudiar libremente en el aula e incluso ir a la escuela a estudiar. En este caso, cambiar la forma de aprender es una forma de coherencia para educarlos en diversas situaciones y condiciones, especialmente durante la pandemia de Covid-19. En este estudio, investigamos cómo la respuesta de los estudiantes a través de futuros maestros de escuela primaria en Indonesia para aprender Educación para la Ciudadanía que se implementó de forma remota en casa con un esquema de aprendizaje en línea durante la pandemia Covid-19. Utilizamos el método de investigación cualitativa y cuantitativa en este estudio. Para recopilar datos, utilizamos cuestionarios distribuidos a 508 estudiantes en la Región Especial de Yogyakarta, Ciudad de Bandung, Ciudad de Cirebon, Provincia de Java Occidental mediante el uso de Google Form. Además, también realizamos algunas entrevistas con varios estudiantes utilizando una aplicación en línea para obtener datos válidos. Según la investigación, hubo buenas y malas actitudes de aprendizaje de los estudiantes en el curso de Educación para la Ciudadanía. Una buena actitud de aprendizaje de los estudiantes se mostró por el entusiasmo en el video basado en el aprendizaje, mientras que la mala actitud de los estudiantes se muestra por la falta de efectividad en la comprensión del concepto de Educación para la Ciudadanía.

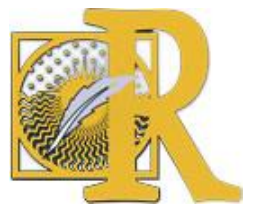

Fecha de recepción: 10-10-2020 Fecha de aceptación: 18-10-2020

Hidayah, Y., Halimah, L., Trihastuti, M., Dewie, D., Feriandi, Y. \& Dianasari, D. (2021). ¿Cómo aprendieron los futuros maestros de escuela primaria en Indonesia la educación para la ciudadanía durante la pandemia de Covid 19? International Journal of Educational Research and Innovation (IJERI), 15, 373-387 


\title{
PALABRAS CLAVE.
}

Covid-19, Educación para la ciudadanía, Indonesia.

\begin{abstract}
.
Number of problems as result of Covid-19 pandemic have continued to appear in various sectors as it rapidly spreads. In education sector, students are no longer able to study freely in classroom and even go to school to study. In this case, changing the way of learning is a form of consistency to educate them in various situations and conditions, especially during the Covid-19 pandemic. In this study, we investigated how the response of students through prospective elementary school teachers in Indonesia to learn Citizenship Education which was implemented remotely at home with an online learning scheme during the Covid-19 Pandemic. We used qualitative and quantitative research method in this study. To collect data, we used questionnaires distributed to 508 students in the Special Region of Yogyakarta, Bandung City, Cirebon City West Java Province by using Google Form. In addition, we also conducted some interviews with a number of students by using an online application to obtain valid data. Based on the research, there were good and bad student learning attitudes in the Citizenship Education course. A good student learning attitude was shown by enthusiasm in the learning-based video, while the bad attitude of students is shown by the lack of effectiveness in understanding the concept of Citizenship Education.
\end{abstract}

\section{KEY WORDS.}

Covid-19, Citizenship Education, Indonesia.

\section{Introduction.}

The pandemic Covid-19 has changed the world due to its rapid spread. A number of reports have informed that the spread of Covid-19 can be through direct contact and respiratory droplets (Association, 2020). Because the spread of Covid-19 is highly rapid, it requires people (around the world) to stay at home and always keep their remote. In this situation, "lockdown" is an alternative way to stop the spread of Covid-19 (Barkur, Vibha, \& Kamath, 2020; Mahato, $\mathrm{Pal}$, \& Ghosh, 2020).

However, it seems that various problems in various sectors actually arise from the "lockdown" scheme; starting from economic, psychological, and social to educational issues. Wijaya (2020) argues that the pandemic has affected many sectors, including the education sector. Fegert, Vitiello, Plener, \& Clemens (2020) inform that according to the World Bank, the result of the Covid-19 pandemic has caused more than 1.6 billion children and adolescents in 161 countries are not attending school.

The "lockdown" has caused endless problems. Poudel \& Subedi (2020) argue that instead of a situation of "lockdown", it actually harms the mental health of individuals. As a factual data, the results of a survey in Istanbul, Turkey by Morgul et al. (2020) has resulted that the mental health of the population due to the Covid-19 pandemic for "attitude" item had shown a positive attitude rather than being tired that COVID-19 would eventually be under control. Therefore, the "lockdown" scheme has a positive and negative side.

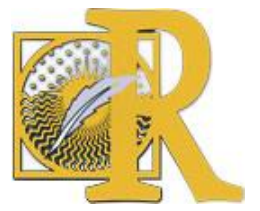

Fecha de recepción: 10-10-2020 Fecha de aceptación: 18-10-2020

Hidayah, Y., Halimah, L., Trihastuti, M., Dewie, D., Feriandi, Y. \& Dianasari, D. (2021). ¿Cómo aprendieron los futuros maestros de escuela primaria en Indonesia la educación para la ciudadanía durante la pandemia de Covid 19 ? International Journal of Educational Research and Innovation (IJERI), 15, 373-387 
The continuity of the learning process has been pursued all over the world. In Indonesia, through Circular Publication Number 4 of 2020 concerning the Implementation of Education Policies in an Emergency Situation as the cause of Covid-19 Spread, learning at home is adjusted to the talents and interests of children. The CNN Indonesia (2020) has reported that the Ministry of Education and Culture of the Republic of Indonesia (KEMENDIKBUD) has provided several programs such as Home Learning to Learning from Home on TVRI and RRI to support students' learning process in every level of education.

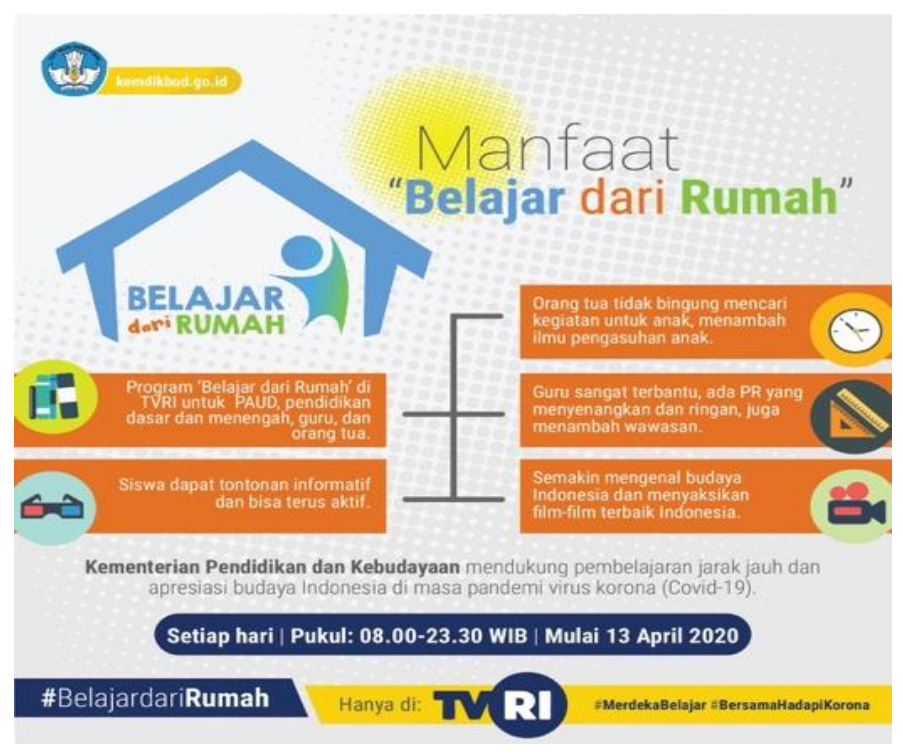

Figure 1. Online Learning Platform by the Ministry of Education and Culture, Indonesia through TVRI. Source: https://disdik.purwakartakab.go.id/berita/detail/kemendikbud-hjual-belajar-darirumah-di-tvri

Based on the use of digital platforms through broadcasting of the Home Learning on TVRI and $\mathrm{RRI}$, the use of technology has played an important role in learning. Several researches have proven the usefulness of technology in learning. Lowerison, Sclater, Schmid, and Abrami (2006) had conducted an investigation on computer technology in higher education learning towards 1,966 sample of students in 81 graduate and undergraduate classes at a large urban university and resulted that there was a relationship between computer technology, active learning, and effectiveness of students. In fact, students who utilize computer technology have obtained a benefit for their active learning.

Furthermore, Shuell and Farber's study (2001) regarding the use of technology in lectures with a sample of 328 respondents representing various disciplines has resulted a positive attitude about the use of technology, and some interesting relationships were found between student learning preferences and evaluation in the learning process. Similarly, Chen, Widarso and Sutrisno's study (2020) which investigated the impact of using Chat-Bots to learn Chinese vocabulary by referring to the Technology Acceptance Model (TAM) has resulted that ChatBot was beneficial for students' learning on Chinese vocabulary with further adjustments.

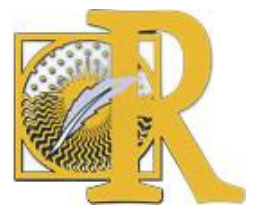


Buzzard, Crittenden, Crittenden, and McCarty (2011) state that current students often refer to "digital generation", because they use technology in various ways. In the context of higher education during Covid-19 pandemic in regard to the use of technology in learning, found that it is sufficient to illustrate the use of technology in the learning process could be a solution even though it still contains lots of improvements.

As one of the individuals who felt the impact of Covid-19 pandemic, the prospective elementary school teachers in the Special Region of Yogyakarta, Bandung City, and Cirebon City had experienced online learning in their lectures. The conventional classroom has turned to online classes by using various digital platforms. Even in online class, the Citizenship Education course was also taught to elementary school teacher candidates during the Covid19 pandemic.

The transformation learning into online classes for elementary school teacher candidates had made them inevitably interact with technology. Moreover, their position as prospective elementary school teacher has made it as a challenge where they must also become prospective elementary school teachers in accordance with current times. In this regard, Murphy and Lebans (2009) state that providing professional learning by using technology to teachers will encourage teachers to build digital literacy and digital competencies that can be applied in the classroom.

Parji and Feriandi (2020) state that there is a need for benchmarks that can be used to measure the learning outcomes of Citizenship Education outside the classroom. Based on these arguments, the use of online classes in the Citizenship Education course for prospective of elementary school teacher has recalled a current idea about mastery of material and concepts in Citizenship Education.

As an urgency, this study investigates how the Indonesian prospective elementary school teacher learn Citizenship Education during the Covid-19 pandemic. This is a critical analysis of the online learning process in the Citizenship Education course, because online learning is one of the challenges in the development of Civic Education. Therefore, as to get a new passion in Citizenship Education especially CE-based online learning, we are highly motivated to conduct this research.

\section{Method.}

The research method used in this study was a combination of qualitative and quantitative method to investigate the response of the Indonesian prospective elementary school teacher to learn Citizenship Education conducted at home in a remote learning scheme during Covid19 pandemic. We distributed questionnaires to 508 students in the Special Region of Yogyakarta, Bandung City, and Cirebon City of West Java Province by using Google Form and processed by using Microsoft Excel and SPSS to find out the responses of prospective elementary school teacher in Citizenship Education learning which was conducted remotely during the pandemic situation.

In this study, we validated the instrument by undergoing three processes, namely content validity, construct validity, and criteria validity. In content validation, the expert team measured several things, namely: 1) defining variables, 2) analyzing questions according to research

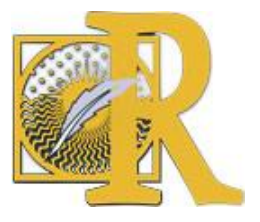

Fecha de recepción: 10-10-2020 Fecha de aceptación: 18-10-2020

Hidayah, Y., Halimah, L., Trihastuti, M., Dewie, D., Feriandi, Y. \& Dianasari, D. (2021). ¿Cómo aprendieron los futuros maestros de escuela primaria en Indonesia la educación para la ciudadanía durante la pandemia de Covid 19? International Journal of Educational Research and Innovation (IJERI), 15, 373-387

ISSN: 2386-4303 DOI https://doi.org/10.46661/ijeri.5329 
variables, 3) determining the number of questions, 4) scaling the instrument, and 5) determining the scale of the instrument.

After completing the content validity, we performed the construct validity. In construct validity, we carried out an extent to which the measuring instrument showed appropriate measurement results. In the measurement process in accordance with the measuring instrument, we referred to Fraenkel, JL, Wallen, NE, \& Hyun, HH (2012) which stated that the questions were structurally constructed in valid when the definition in adjusting the measuring instrument was based on proper and relevant theory, so that the questions in the instrument were correct.

In the final step, we performed criteria validity. In this validity, we compared the instrument with other instruments as referred to the opinion of Fraenkel, JL, Wallen, NE, \& Hyun, HH (2012) that the validity of the two criteria was the validity of the predictive criteria and concurrent criteria. In the predictive criteria validity, we processed it at the same time, while we performed concurrent criteria validity in testing the instrument with the criteria.

After completing the three validity processes, we processed the results of the instruments (see Table 1). In this case, we distributed questionnaires from April 2020 to May 2020 in the Special Region of Yogyakarta, Bandung City, Cirebon City West Java Province by using Google Form.

Table 1. Questionnaire of Students' Attitudes towards Remotely Citizenship Education Learning

\begin{tabular}{|c|c|c|c|c|c|}
\hline \multirow[t]{2}{*}{ No } & \multirow[t]{2}{*}{ Statement } & \multicolumn{4}{|c|}{ Answer } \\
\hline & & Very agree & Agree & Disagree & Very Disagree \\
\hline 1 & $\begin{array}{l}\text { I do like learning Citizenship Education } \\
\text { remotely. }\end{array}$ & & & & \\
\hline 2 & $\begin{array}{l}\text { Learning Citizenship Education remotely is } \\
\text { easy to understand. }\end{array}$ & & & & \\
\hline 3 & $\begin{array}{l}\text { I have a difficulty in learning Citizenship } \\
\text { Education remotely online. }\end{array}$ & & & & \\
\hline 4 & $\begin{array}{l}\text { Remote learning for Citizenship Education } \\
\text { is more interesting than face-to-face } \\
\text { learning. }\end{array}$ & & & & \\
\hline 5 & $\begin{array}{l}\text { I am easier to explain a problem related to } \\
\text { Citizenship Education remotely. }\end{array}$ & & & & \\
\hline 6 & $\begin{array}{l}\text { As a prospective elementary scholl teacher, } \\
\text { remote learning for Citizenship Education } \\
\text { can make me well-prepared to be an } \\
\text { elementary school teacher. }\end{array}$ & & & & \\
\hline 7 & $\begin{array}{l}\text { As a prospective elementary scholl teacher, } \\
\text { I feel that remote learning for Citizenship } \\
\text { Education is far more contextual. }\end{array}$ & & & & \\
\hline 8 & $\begin{array}{l}\text { Remote learning for Citizenship Education } \\
\text { has given me a motivation to a good } \\
\text { elementary school teacher. }\end{array}$ & & & & \\
\hline 9 & $\begin{array}{l}\text { Remote learning for Citizenship Education } \\
\text { has made me more comprehensive in } \\
\text { understanding problems in the community. }\end{array}$ & & & & \\
\hline
\end{tabular}

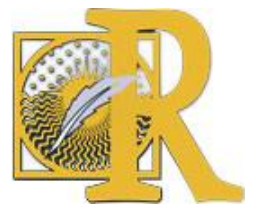


10 Remote learning for Citizenship Education becomes my personal support to be professional elementary school teacher.

In addition, we also conducted some interview sections on a number of students by using an online application to obtain valid data regarding the responses of prospective elementary school teacher to learn Citizenship Education in remote learning.

Table 1. The Percentage of Prospective Elementary School Teacher regarding Remote Learning for Citizenship Education

\begin{tabular}{c|c|}
\hline Percentage & Interpretation \\
\hline $0<x<25$ & Very Bad \\
\hline $26<x<50$ & bad \\
\hline $51<x<75$ & Good \\
\hline $76<x<100$ & Very Good \\
\hline
\end{tabular}

\section{Result}

\begin{tabular}{|c|l|l|l|l|l|}
\hline Item number & Type & Answer & & \\
\cline { 4 - 6 } & Statement & Very agree & Agree & Disagree & Very Disagree \\
\hline 1 & Positive & & $68.87 \%$ & & \\
\hline 2 & Positive & & $80.98 \%$ & & \\
\hline 3 & Negative & & & $76.89 \%$ & \\
\hline 4 & Negative & & $90,5 \%$ & & \\
\hline 5 & Positive & & $80,11 \%$ & & \\
\hline 6 & Positive & & $92,45 \%$ & & \\
\hline 7 & Positive & $70,5 \%$ & & & \\
\hline 8 & Positive & $80,5 \%$ & & & \\
\hline 9 & Positive & & $75,5 \%$ & & \\
\hline 10 & Positive & $98,8 \%$ & & & \\
\hline
\end{tabular}

Based on the results of the distribution of Google Form, the respondents who answered "disagree" and "strongly disagree" with the statements given in the average percentage of respondents was $76.89 \%$ disagree, $68.87 \%$ agree, $80.98 \%$ agree, $90,5 \%$ agree, $80,11 \%$

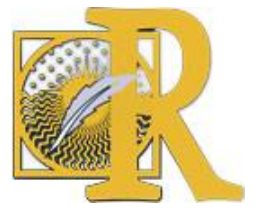




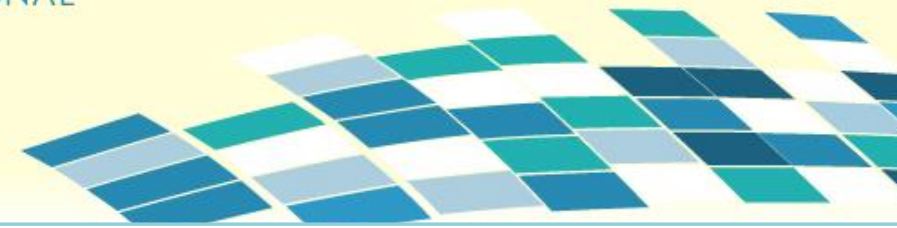

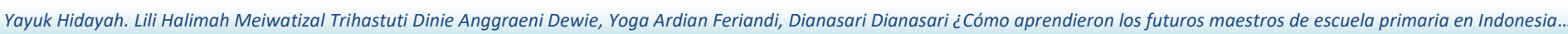

agree, $92,45 \%$ agree, $75,5 \%$ agree which showed that almost respondents responded to the remote learning scheme for Citizenship Education.

In similar concept, a study by Ellahi and Zaka (2015) which investigated remote (remote) education in Pakistan highlighted certain opportunities that could help to strengthen remote education policies. The finding has become a recommendation for remote learning policies to produce desired results. In addition, Miller and Rector's study (2002) regarding remote learning in the nursing credentials program, has resulted that the perceptions of students and instructors on remote learning had conducted an evaluation that included methodology, more available educational alternatives and quality of learning outcomes. Apart from it, Upvall, Decker and Wilkerson's study (2000) regarding remote learning across rural Arizona in the US has resulted that an emerging element of remote learning was learning, teaching and support for learning and teaching itself.

The results of research on remote learning for Citizenship Education have indicated that this model of learning was not so boring for students. Factually, students have an increased ability to learn through technology. For example, a group of students explains the development of the Covid19 case in their respective regions through video as in the following figure.
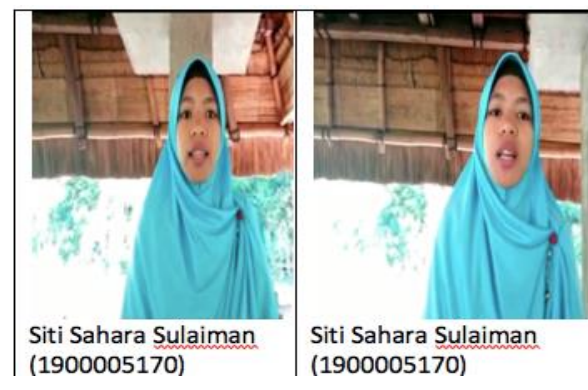

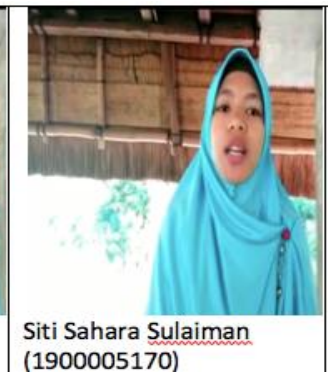

(a)

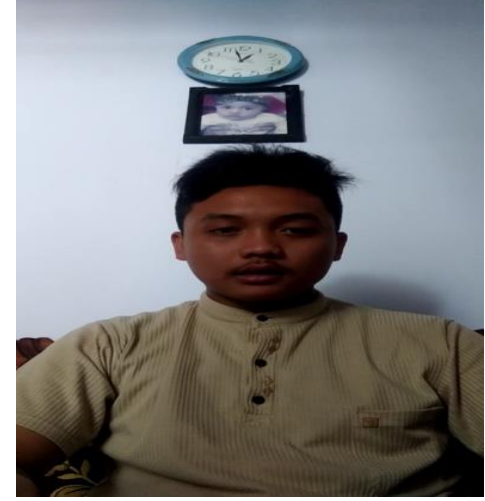

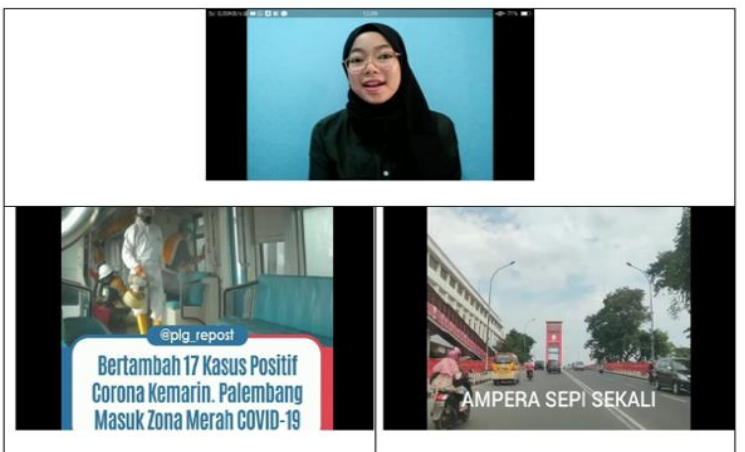

(b)

Figure 1. Students explain the development of the Covid19 Case in their respective regions through video.

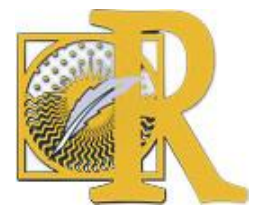

Fecha de recepción: 10-10-2020 Fecha de aceptación: 18-10-2020

Hidayah, Y., Halimah, L., Trihastuti, M., Dewie, D., Feriandi, Y. \& Dianasari, D. (2021). ¿Cómo aprendieron los futuros maestros de escuela primaria en Indonesia la educación para la ciudadanía durante la pandemia de Covid 19? International Journal of Educational Research and Innovation (IJERI), 15, 373-387 
In addition, the interviews with respondents regarding remote learning for Citizenship Education course also resulted that students could also grasp the concepts and materials in Citizenship Education. This is in line with Scagnoli's statement (2009) that forms of learning in tertiary institutions have increased exponentially in the last decade. The previous statement indicates that students can study, explore and get an overview of how their citizenship knowledge can increase through Citizenship Education.

The results of interviews with respondents also showed that through remote learning for Citizenship Education, students could contextualize values and norms, so that the character of a tough citizen could be formed. In the same perspective, a study by Rifai (2016) in contextualizing learning has resulted that designing instruction and describing how instruction contributes has enabled teachers to educate students by using critical pedagogy and interdisciplinary learning. Another study regarding predictors of experiential learning in-team, has focused on one variable, that was psychological safety (Sanner \& Bunderson, 2015). The study proclaimed that in almost these jobs, psychological safety was seen as a direct predictor of team learning. In this study, we suggest that this work has ignored the critical effects of the nature of the task environment on psychological safety capacity in order to have a beneficial effect. To investigate this, we conducted a comprehensive study with meta-analysis which examines the relationship between psychological safety, team learning, and team performance. We found that psychological safety was more closely related to learning and performance in some subjects conducted in the form of knowledge-intensive task settings, namely settings which involved complexity, creativity, and sense making. The results of this study suggested that psychological safety might not be sufficient to stimulate learning in groups whose task environments did not require learning.

In addition, although remote learning for Citizenship Education was limited with facilities such as the existence of a strong internet connection and adequate devices, they were able to become role models in improving the material and concepts of Student Citizenship Education in their daily lives. The following figure is the result of student responses regarding remote learning for Citizenship Education.

Table 2. Student responses to remote learning for Citizenship Education.

\begin{tabular}{|c|l|l|}
\hline No & Student & Response on the Concept of Citizenship Education \\
\hline 1 & $\begin{array}{l}\text { Students' respond on remote learning } \\
\text { for Citizenship Education. }\end{array}$ & $\begin{array}{l}\text { Remote learning for Citizenship Education can approach } \\
\text { students to daily problems in the community. }\end{array}$ \\
\hline 2 & Citizenship Knowledge. & $\begin{array}{l}\text { Has an academic competence based on the theory, political } \\
\text { concept, law, and moral. }\end{array}$ \\
\hline 3 & Citizenship Attitude. & $\begin{array}{l}\text { Includes intellectual skills and participatory skills in state and } \\
\text { nation life. }\end{array}$ \\
\hline 4 & Citizenship Behavior. & Character and the application of nationalism. \\
\hline 5 & $\begin{array}{l}\text { Contribute to be smart and good } \\
\text { citizenship }\end{array}$ & Understanding rights and obligations as Indonesia citizen. \\
\hline
\end{tabular}


The above table has indicated that Citizenship Education requires a kind of national movement which must be a joint commitment to realize smart and good citizenship in Indonesia. In this commitment, Nagro, Fraser, and Hooks (2018) argued that the struggle between the aspirations of bottom-up participatory democracy and authoritarian control has produced the skills of citizens who have a state of consciousness.

Again, strengthening the material and concept of Citizenship Education is a good media for shaping and realizing the success of Citizenship Education learning and shaping the character of the nation. Yuen (2016) states that Citizenship education is a way of nurturing citizens to become good citizen. Besides, Tolstenko, Baltovskij, and Radikov (2019) strengthen that the education process is actually to form active citizens, so that in the context of Indonesia, Citizenship Education accommodates the implementation of student skills in order that they have good character as the Indonesian.

\section{Discussion.}

\section{Enthusiasm in Citizenship Education Remote Learning.}

Remote learning for Citizenship Education can be a means to form and create citizens who understand and know their rights and obligations in state life. In this case, Wahab and Sapriya (2011) proclaim that citizens who are qualified good in the context of Indonesia are citizens who understand their rights and obligations and they can contribute to democratic life.

The enthusiasm for remote learning for Citizenship Education had shown positive impression. It meant that students had experienced their activities outside the classroom through some suggested media of learning. In regard to this result, Hidayah, Sapriya, Darmawan, and Malihah (2020) stated that the outside classroom activities could strengthen students' skills as citizen. Similarly, a study by Lakin and Wichman (2005) also found that students who applied learning activities to the real world had found it easier to apply their knowledge. Thus, enthusiasm in remote learning for Citizenship Education can strengthen the cultivation of knowledge and forming students' attitudes, so that students can finally behave in accordance with the rules that apply in society.

Furthermore, remote learning for Citizenship Education had found generated high learning enthusiasm of students and could provide meaningful learning. In line with this finding, Jackson and Shenton (2010) also found that the area of self-learning played a role in encouraging collaborative individual work to solve the diversity of their life situations. In this case, integrating Citizenship Education material is greatly important to implement and adjust learning studies to current conditions and pay attention to students' needs.

The remote implementation for Citizenship Education course in the topic of "the rights and obligations of citizens", "human rights", "democracy", "the constitution", and "the rule of law", has eternally delivered enthusiasm for learning that can increase their knowledge of citizenship. Emo, Emo, Kimn, and Gent (2015) respond to this phenomena that students' learning is an interaction of experience and environment. Therefore, it gives an indication that Citizenship Education can be a vehicle for education with a mission to develop citizens who believe and rely on the state and constitution of the Republic of Indonesia.

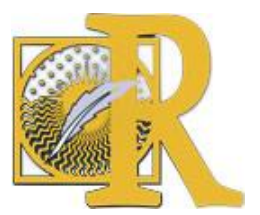

Fecha de recepción: 10-10-2020 Fecha de aceptación: 18-10-2020

Hidayah, Y., Halimah, L., Trihastuti, M., Dewie, D., Feriandi, Y. \& Dianasari, D. (2021). ¿Cómo aprendieron los futuros maestros de escuela primaria en Indonesia la educación para la ciudadanía durante la pandemia de Covid 19 ? International Journal of Educational Research and Innovation (IJERI), 15, 373-387 
The enthusiasm in Citizenship Education remote learning was schemed and portrayed through Citizenship Education participation in the learning process. In this regard, Westheimer \& Kahne (2004) argued that teaching democracy must also pay attention to political and ideological interests in various conceptions of citizenship. They also assumed that there were two ways to perform it, namely through school programs that can develop responsibility in state life, and by using various services that were useful in classifying participatory Citizenship Education and justice. Based on this opinion, the participation of Citizenship Education seen in remote learning in the midst of Covid-19 can be performed by emphasizing participatory and effective Citizenship Education.

The achievement of learning objectives is a systematically planned process. Nagro, Fraser, and Hooks (2018) state that the success of educators in learning is sufficiently important for students, but teachers are challenged every day to get various models of learning to improve students' behavior. Therefore, remote learning for Citizenship Education is a form of guidance in realizing good and smart citizens. This commitment can reinforce the lack of moral teaching, value, and norm which currently has only reached cognitive aspect as it can create misunderstanding on the concept of Citizenship Education whose relation is completely related with rights and obligations as citizens.

The emergence of enthusiasm in Citizenship Education in the mode of remote learning that can create experience of "ask questions, discuss, think critically or participate in project work and problem solving for students", has been realized. Related to previous phenomena, You (2020) argued that translating (transforming) experience into knowledge would be able to guide students consistently in transforming their morals in their life. Therefore, through remote learning for Citizenship Education set free for students to not only memorizing, but rather learning visually as well as it can improve the quality of their critical thinking.

\section{The Concept of Citizenship Education.}

Understanding the concepts of Citizenship Education factually emphasizes knowledge construction carried out by students during Citizenship Education remote learning. In this regard, Delgado-Algarra et al (2019) argued that the sustainability model of citizenship was what could make citizens taking a role in their civil life. Therefore, in understanding the concept of Citizenship Education, knowledge should be build that students as citizens have a role, rights, and responsibilities.

Factually, there are still ethics, morals, and norms that have been taught only at the cognitive level, so that education is suggested to be more creative in internalizing social moral values. There is a necessary to understand the concept of Citizenship Education in order to break the understanding of Citizenship Education course. Hidayah, Sapriya, Darmawan, Malihah, and Karliani (2020) state that citizenship intelligence is the accumulation of intelligence to be a citizen. Therefore, it is the time to strengthen the concept of Citizenship Education where the presentation of the topic is not only limited to conventional methods, but also ethical, moral, and norm issues should have led to actions and practices that often raise concerns.

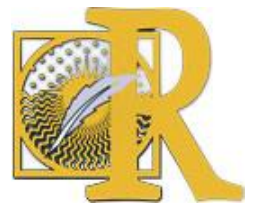

Fecha de recepción: 10-10-2020 Fecha de aceptación: 18-10-2020

Hidayah, Y., Halimah, L., Trihastuti, M., Dewie, D., Feriandi, Y. \& Dianasari, D. (2021). ¿Cómo aprendieron los futuros

maestros de escuela primaria en Indonesia la educación para la ciudadanía durante la pandemia de Covid 19 ? International Journal of Educational Research and Innovation (IJERI), 15, 373-387

ISSN: 2386-4303 DOI https://doi.org/10.46661/ijeri.5329 
Understanding the concept of Citizenship Education in the form of remote learning should use and consider various learning intermediaries, including technology. Awidi, Paynter, and Evers (2019) state that educational institutions can take advantage of the attributes of digital devices to enhance their students' learning. It is therefore Citizenship Education has a different strategic position in carrying out the mission to create smart and responsible citizens in the Indonesian context.

Furthermore, Darmawan (2015) states that several socio-political factors that are important in the life of the state, namely corruption, transparency and accountability, intellectual capacity and the responsibility of the legislature towards society are also required to be exposed in Citizenship Education learning. Therefore, by understanding the concept of Citizenship Education, it is expected that it can be a personality development course for students.

Concisely speaking, Indonesia is a unique with Pancasila as the basis of the state. Riyanto (2007) states that Pancasila is formulated by the founders of the nation and established by the Preparatory Committee for Indonesian Independence on August 18, 1945 as the basis of the Indonesia. For this reason, it is appropriate that through Citizenship Education paradigm on Pancasila as the basis for the state continuously be implemented to excite the younger generation.

Winataputra and Budimansyah (2017) state that Citizenship Education has a sociopedagogical mission as the development of individual potentials as the God and social beings to become intelligent, democratic, law-abiding, civilized and religious Indonesian citizens. The socio-cultural mission is to facilitate the realization of ideals in the context of Indonesian, while the substantive-academic mission is to develop a structure of knowledge (constellation spectrum) of Citizenship Education. Therefore, a remote learning for Citizenship Education will be able to contribute to the realization of democratic, intelligent, law-abiding, and religious Indonesian that are ultimately integrated into the Citizenship Education course.

\section{Conclusion}

Based on this study, we can take some reflections to conclude, namely:

1) The Covid-19 pandemic is not an obstacle for prospective elementary school teacher to conduct Citizenship Education course. Students can study independently in a remote learning scheme that has been prepared by using the e-Learning platforms.

2) The results of the observation had shown that the average student viewed that remote learning could provide good learning outcomes. In addition, the existence of learning through videos for Citizenship Education course could increase enthusiasm and understanding of concepts in Citizenship Education course.

3) The results of the interview also showed that prospective elementary school teacher could perfectly and appropriately respond to remote learning for Citizenship Education course. In addition, they also respond to the existence of instructional videos in Citizenship Education lecture as a substitute for face-to-face learning model in conventional classroom. 
4) Enthusiasm in Citizenship Education remote learning is to emphasize participatory and effective Citizenship Education. In relation to this study, enthusiasm is seen in various actions in Citizenship Education remote learning that leads students to a participatory process.

5) Understanding of the concept of Citizenship Education remote learning during the Covid-19 pandemic in Indonesia has been converted to participatory and effective Citizenship Education to form a construction of knowledge about the rights and obligations of state citizenship for students.

By this point, we expect that the results of this study can be used as information on how prospective elementary school teacher can conduct Citizenship Education course in any emergency situation by modifying and design the course into technology-based learning.

\section{References.}

- Association, S. E. G. for C. of the E. of N. C. P. of the C. P. M. (2020). An update on the epidemiological characteristics of novel coronavirus pneumonia (COVID-19). Zhonghua liu xing bing xue za zhi = Zhonghua liuxingbingxue zazhi, 41(2). https://doi.org/10.3760/cma.j.issn.0254-6450.2020.02.002

- Awidi, I. T., Paynter, M., \& Evers, U. (2019). Visual Organizers and Scaffolding the Student Learning Experience in Higher Education. Journal of Educational Technology Systems, 48(4), 518-538. https://doi.org/10.1177/0047239519893051

- Barkur, G., Vibha, \& Kamath, G. B. (2020). Sentiment analysis of nationwide lockdown due to COVID 19 outbreak: Evidence from India. Asian Journal of Psychiatry, 51, 1-2. https://doi.org/10.1016/j.ajp.2020.102089

- Buzzard, C., Crittenden, V. L., Crittenden, W. F., \& McCarty, P. (2011). The Use of Digital Technologies in the Classroom: A Teaching and Learning Perspective. Journal of Marketing Education, 33(2), 131-139. https://doi.org/10.1177/0273475311410845

- Chen, H.-L., Vicki Widarso, G., \& Sutrisno, H. (2020). A ChatBot for Learning Chinese: Learning Achievement and Technology Acceptance. Journal of Educational Computing Research, 58(6), 1161-1189. https://doi.org/10.1177/0735633120929622

- CNN Indonesia. (2020). Kemendikbud Buat Skenario Belajar di Rumah sampai Akhir 2020. CNN Indonesia. Diambil dari. Retrieved from: https://www.cnnindonesia.com/nasional/20200424114337-20-496861/kemendikbud-buatskenario-belajar-di-rumah-sampai-akhir-2020

- Darmawan, C. (2015). Legislative Strengthening and Empowerment: Efforts to Strengthen Local Governance and Accountability through Provincial Parliaments in Indonesia.

American Journal of Applied Sciences, 12, 802-809.

https://doi.org/10.3844/ajassp.2015.802.809 
- Delgado-Algarra, E., Román-Sánchez, I., Olmedo, E., \& Lorca Marín, A. (2019). International MOOC Trends in Citizenship, Participation and Sustainability: Analysis of Technical, Didactic and Content Dimensions. Sustainability, 11. https://doi.org/10.3390/su11205860

- Fraenkel, J. L., Wallen, N. E., \& Hyun, H. H.. (2012). How to design and evaluate research in education eighth edition. New York: Mc Graw Hill.

- Ellahi, A., \& Zaka, B. (2015). Analysis of Higher Education Policy Frameworks for Open and Distance Education in Pakistan. Evaluation Review, 39(2), 255-277. https://doi.org/10.1177/0193841X15570046

- Emo, K., Emo, W., Kimn, J.-H., \& Gent, S. (2015). The Complex Experience of Learning to Do Research. Journal of Experiential Education, 38(4), 339-353. https://doi.org/10.1177/1053825915578913

- Fegert, J. M., Vitiello, B., Plener, P. L., \& Clemens, V. (2020). Challenges and burden of the Coronavirus 2019 (COVID-19) pandemic for child and adolescent mental health: a narrative review to highlight clinical and research needs in the acute phase and the long return to normality. Child and Adolescent Psychiatry and Mental Health, 14(1), 20. https://doi.org/10.1186/s13034-020-00329-3

- Hidayah, Y., Sapriya, Darmawan, C., Malihah, E., \& Karliani, E. (2020). Promoting Civic Intelligence in Applied Science to Promote Interaction between Science: An Overview in the Perspective of Citizenship Education. Universal Journal of Educational Research, 8(8), 3782-3791. https://doi.org/10.13189/ujer.2020.080859.

- Hidayah, Y., Sapriya, S., Darmawan, C., \& Malihah, E. (2020). Student Organizations as Voluntary Groups in Tertiary Education: Enculturation and Balancing Political Engagement for Indonesian Generation Z. he International Journal of Civic, Political, and Community Studies, 18(1). https://doi.org/10.18848/2327-0047/CGP/v18i01/1-12

- Jackson, M., \& Shenton, A. K. (2010). Independent learning areas and student learning. Journal of Librarianship and Information Science, 42(4), 215-223. https://doi.org/10.1177/0961000610380821

- Lakin, J. L., \& Wichman, A. L. (2005). Applying Social Psychological Concepts outside the Classroom. Teaching of Psychology, 32(2), 110-113. https://doi.org/10.1207/s15328023top3202_7

- Lowerison, G., Sclater, J., Schmid, R. F., \& Abrami, P. C. (2006). Are We Using Technology for Learning? Journal of Educational Technology Systems, 34(4), 401-425. https://doi.org/10.2190/ER58-3H7P-Y8FK-U8F7

- Mahato, S., Pal, S., \& Ghosh, K. (2020). Effect of lockdown amid COVID-19 pandemic on air quality of the megacity Delhi, India. Science of The Total Environment, 730, 139086. https://doi.org/10.1016/j.scitotenv.2020.139086 
- Miller, B., \& Rector, C. (2002). Distance Learning in a School Nurse Credential Program. The Journal of School Nursing, 18(6), 338-345. https://doi.org/10.1177/10598405020180060601

- Morgul, E., Bener, A., Atak, M., Akyel, S., Aktaş, S., Bhugra, D., ... Jordan, T. R. (2020). COVID-19 pandemic and psychological fatigue in Turkey. International Journal of Social Psychiatry, 0020764020941889. https://doi.org/10.1177/0020764020941889

- Murphy, J., \& Lebans, R. (2009). Leveraging New Technologies for Professional Learning in Education: Digital Literacies as Culture Shift in Professional Development. E-Learning and Digital Media, 6(3), 275-280. https://doi.org/10.2304/elea.2009.6.3.275

- Nagro, S. A., Fraser, D. W., \& Hooks, S. D. (2018). Lesson Planning With Engagement in Mind: Proactive Classroom Management Strategies for Curriculum Instruction. Intervention in School and Clinic, 54(3), 131-140. https://doi.org/10.1177/1053451218767905

- Parji, \& Feriandi, Y. A. (2020). Development of Student Participation Instruments in Politics for Civic Education Learning in the University. Universal Journal of Educational Research, 8(8), 3679-3689. https://doi.org/10.13189/ujer.2020.080847.

- Poudel, K., \& Subedi, P. (2020). Impact of COVID-19 pandemic on socioeconomic and mental health aspects in Nepal. International Journal of Social Psychiatry, 0020764020942247. https://doi.org/10.1177/0020764020942247

- Rifai, A. (2016). Learning through Immersive Study: Contextualizing Music in the Elementary Music Classroom. Music Educators Journal, 103(1), 34-40. https://doi.org/10.1177/0027432116655198

- Riyanto, A. (2007). Pancasila Dasar Negara Indonesia. Junal Hukum dan Pengembangan, $37(3), 457-493$.

- Sanner, B., \& Bunderson, J. S. (2015). When feeling safe isn't enough: Contextualizing models of safety and learning in teams. Organizational Psychology Review, 5(3), 224-243. https://doi.org/10.1177/2041386614565145

- Scagnoli, N. (2009). A Review of Online Learning and its Evolution in Latin America. Policy Futures in Education, 7(5), 555-565. https://doi.org/10.2304/pfie.2009.7.5.555

- Shuell, T. J., \& Farber, S. L. (2001). Students' Perceptions of Technology Use in College Courses. Journal of Educational Computing Research, 24(2), 119-138. https://doi.org/10.2190/YWPN-H3DP-15LQ-QNK8

- Tanu Wijaya, T. (2020). How chinese students learn mathematics during the coronavirus pandemic. IJERI: International Journal of Educational Research and Innovation, 15, 1-16. https://doi.org/10.46661/ijeri.4950

- Tolstenko, A., Baltovskij, L., \& Radikov, I. (2019). Chance of Civic Education in Russia. SAGE Open, 9(3), 2158244019859684. https://doi.org/10.1177/2158244019859684

- Upvall, M. j., Decker, I., \& Wilkerson, E. (2000). Essentials of a successful distance-learning experience. NT Research, 5(3), 215-225. https://doi.org/10.1177/136140960000500309

- Wahab, A. A., \& Sapriya. (2011). Teori dan Landasan Pendidikan Kewarganegaraan. Bandung: CV Alfabeta.

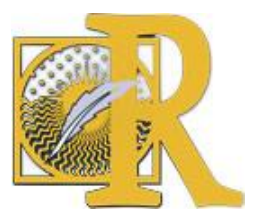


- Westheimer, J., \& Kahne, J. (2004). Educating the "Good" Citizen: Political Choices and Pedagogical Goals. PS: Political Science \& Politics, 37(2), 241-247. doi:10.1017/S1049096504004160

- Winataputra, U. S., \& Budimansyah., D. (2017). Civic Education, Konteks, Landasan, Bahan Ajar dan Kultur Kelas. Bandung: UPI.

- You, Y. (2020). Learning Experience: An Alternative Understanding Inspired by Thinking Through Confucius. ECNU Review of Education, 3(1), 66-87. https://doi.org/10.1177/2096531120904247

- Yuen, T. W. W. (2016). Civic education stuck in a quagmire: A critical review of civic education in Hong Kong? Citizenship, Social and Economics Education, 15(2), 69-82. https://doi.org/10.1177/2047173416650447 